\title{
Seawater intrusion due to pumping mitigated by natural freshwater flux: a case study in Wladysławowo, northern Poland
}

\author{
Malgorzata Pruszkowska-Caceres ${ }^{1}$, Adam Szymkiewicz ${ }^{1}$, Beata Jaworska-Szulc ${ }^{1}$, Maria \\ Przewłócka $^{1}$, Anna Gomuła-Kawęcka ${ }^{1}$, Dawid Potrykus ${ }^{1}$ \\ ${ }^{1}$ Gdańsk University of Technology, Faculty of Civil and Environmental Engineering
}

\begin{abstract}
The paper presents a case study of seawater intrusion into a coastal aquifer, caused by a groundwater intake located close to the seashore in Władysławowo, northern Poland. Evolution of the basic hydrogeochemical parameters for the 50-year period from 1964 to 2014 indicates progressing encroachment of saline seawater into the aquifer. However, the spatial pattern of salinity was influenced by the variability of hydraulic gradient in fresh water discharging from aquifer to the sea. As a consequence, significant changes in salinity occurred in the directions both perpendicular and parallel to the coastline.
\end{abstract}

\section{INTRODUCTION}

The main goal of this study was investigation of temporal and spatial variability of the basic hydrogeochemical parameters in the vicinity of a coastal groundwater intake in Władysławowo, for the period from 1964 to 2014. Particular attention is paid to the role of natural hydrogeological conditions as a factor enhancing or limiting saltwater intrusion caused by groundwater abstraction.

Władysławowo is situated in northern Poland, at the base of the Hel Peninsula, on the border of the upland moraine area of Kępa Swarzewska (Fig. 1). There are two Quaternary aquifers. The shallow one is composed of Pleistocene and Holocene sandy and gravel marine and glacial sediments. Currently it is not exploited. The deeper aquifer, composed of Pleistocene sands and gravel of thickness 16 to $70 \mathrm{~m}$, occurs at depth -8 to $-44 \mathrm{~m}$ a.s.1., however in the area of the moraine upland the depth increases to about $-100 \mathrm{~m}$ a.s.l. It is covered by 25 to $35 \mathrm{~m}$ thick detached block of Miocene clay-silt sediments transported by glacier and deposited over Pleistocene layer. Locally it is covered by 5 to $80 \mathrm{~m}$ thick layer of Pleistocene boulder clay (Fig. 1). The hydraulic conductivity of the deeper aquifer ranges from $0.43 \mathrm{~m} / \mathrm{h}$ to $1.55 \mathrm{~m} / \mathrm{h}$. The potentiometric surface occurs at 3.7 to $6.2 \mathrm{~m} \mathrm{b.g.1}$. (0.3 to $6.1 \mathrm{~m}$ a.s.1.). However, due to intensive exploitation the level has decreased to -1.8 meters a.s.1., causing saltwater intrusion. Previous research based on the concentration of tritium (TU 5.8 to 13.5) showed that there is approximately $40 \%$ of marine origin water in the deeper Quaternary aquifer of the Władysławowo area (Kozerski and Pruszkowska, 1996). In the same analysis the possibility of another origin of the salinity was ruled out. Groundwater recharge of the aquifers takes place on Kępa Swarzewska - as direct infiltration and lateral inflow, and on the Żarnowiecka moraine upland - as lateral far distance inflow (Pruszkowska 2005). Both aquifers discharge to the Baltic Sea, the shallower one has direct contact with the seaside, while the deeper aquifer has an outcrop in the sea bottom, where submarine discharge predominates.

Groundwater from the deeper aquifer was abstracted continuously from 1964 to 2014 for the needs of a fish processing plant. Currently the wells are used as an emergency water supply. The intake consists of 6 wells aligned along the coast (Fig 1). The western wells $(415,423)$ 
worked with discharge up to $42 \mathrm{~m}^{3} / \mathrm{h}$, while the discharge of the other wells did not exceed $20 \mathrm{~m}^{3} / \mathrm{h}$.

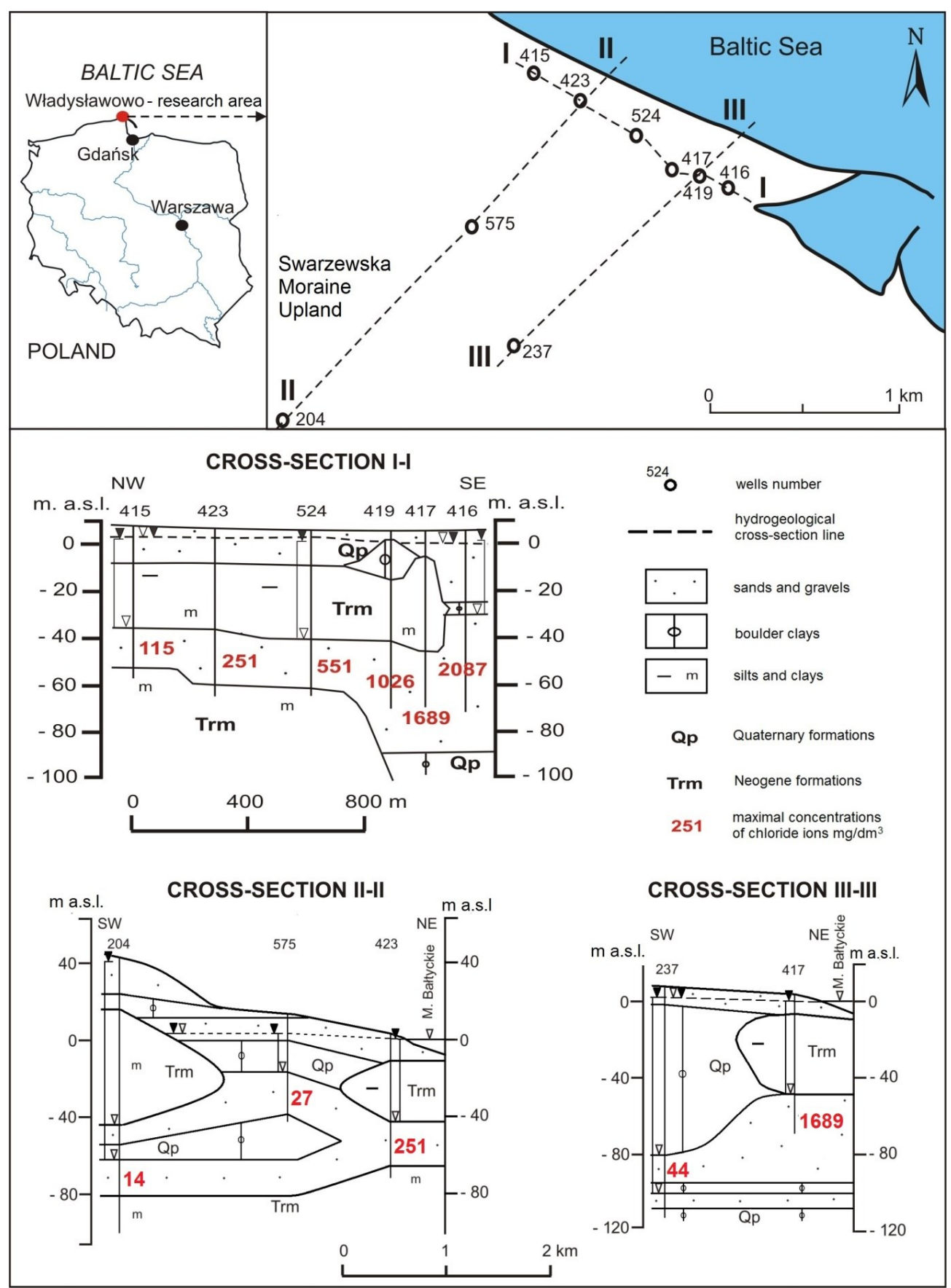

Figure 1. Hydrogeological cross-sections and location of the research area.

\section{METHODS}

We collected archival data on the chloride and sulphate concentrations measured in the 6 pumping wells of the intake between 1964 and 1994. The samples for chemical analyses were taken from the lowest part of each well in July each year. Between 1998 and 2014 we conducted sampling and analysis, also taking samples from the lowest part of each well. The chemical analyses included TDS and main dissolved ions ( $\mathrm{Na}, \mathrm{K}, \mathrm{Ca}, \mathrm{Mg}, \mathrm{Cl}, \mathrm{SO} 4, \mathrm{HCO} 3)$, 
as well as $\mathrm{Br}, \mathrm{Sr}, \mathrm{pH}$, Eh and temperature. Besides the abstraction wells, we included monitoring wells 204, 237, 575 (Fig. 1) and samples of water from the Baltic Sea. Additionally, in 2004 a more detailed series of measurements was carried out to capture the vertical salinity profiles In each of the wells samples were taken from a range of depths, starting from $2 \mathrm{~m}$ below the top of aquifer, down to the bottom of the well in $5 \mathrm{~m}$ intervals.

Based on the most recent measurements from 2014 the hydrogeochemical types of sampled groundwater were determined, according to the proposition of Stuyfzand (1989). This classification scheme distinguishes between fresh $(\mathrm{F},<300 \mathrm{Cl})$, fresh-brackish, brackish, brackish-saline (Bs), saline (S) and Hypersaline (H) waters. Further division is based on the dominant ion groups and dominant ions within each group. The Base Exchange Index (BEX) was calculated as $\mathrm{BEX}=\mathrm{Na}+\mathrm{K}+\mathrm{Mg}-1.071 \mathrm{Cl}$, where the concentrations are given in $\mathrm{mval} / \mathrm{dm}^{3}$ (Stuyfzand 1989, 2008). Several other indices, frequently used in seawater intrusion studies were determined (Appelo \& Postma 2004, Bear et al. 1999). They include the following ratios: $\mathrm{Na} / \mathrm{Cl},(\mathrm{Ca}+\mathrm{Mg}) / \mathrm{Cl}, \mathrm{Ca} /(\mathrm{HCO} 3+\mathrm{SO} 4), \mathrm{Cl} / \mathrm{Br}, \mathrm{Ca} / \mathrm{Sr}$ (all concentrations expressed in $\left.\mathrm{mval} / \mathrm{dm}^{3}\right)$.

\section{RESULTS AND DISCUSSION}

The temporal variability of $\mathrm{Cl}^{-}$and $\mathrm{SO}_{4}{ }^{-2}$ concentrations is presented in Figure 2 for each well of the intake. In 1964, before groundwater exploitation began, concentrations of each ion were similar in all wells. The chloride concentration varied in the range from 11 to 32 $\mathrm{mg} \mathrm{Cl} / \mathrm{dm}^{3}$, sulphate from 12 to $40 \mathrm{mg} \mathrm{SO} / \mathrm{dm}^{3}$., which can be considered typical for Pleistocene aquifers of the region (Pruszkowska \& Malina 2008). Due to continuous water uptake an increase in the ion concentrations was observed during the whole considered period. This increase was unevenly distributed along the line of wells (Fig. 2). The largest concentrations were measured in well 416 (in 2014: $2087 \mathrm{mg} \mathrm{Cl} / \mathrm{dm}^{3}, 421 \mathrm{mg} \mathrm{SO} 4 / \mathrm{dm}^{3}$ ), while in well 415 at the opposite end of the line the increase was much smaller (in 2014: $115 \mathrm{mg} \mathrm{Cl} / \mathrm{dm}^{3}, 32 \mathrm{mg} \mathrm{SO} 4 / \mathrm{dm}^{3}$ ).

This spatial variability can be explained by several factors. Well 416 is practically surrounded by sea, being situated not only close to the main shore line but also in the vicinity of a local harbor bay. Moreover, the hydrogeological cross sections in Fig. 1 show that the hydraulic gradient in the direction perpendicular to the sea coast is much larger in the northwest end of the intake (wells 415 and 423, cross-section II-II) than in the south-east end (wells 417 and 416, cross-section III-III). Thus one can expect larger discharge flux of fresh water in the aquifer close to well 415 , compared to the discharge flux in the vicinity of well 416. Additionally, the considered aquifer is significantly thicker in the eastern part, which possibly facilitates encroachment of saline water in its lower part. Yet another factor which may affect the non-uniform evolution of groundwater salinity is the variable confinement of the deeper aquifer. As shown in Fig. 1, near well 416 the confining stratum is relatively thin and possibly semi-permeable. Such a situation can potentially facilitate the contact with the saline water from the sea and the shallow aquifer. Note that the pattern of salinity was completely opposite to the distribution of the well discharge, with western well pumping rates twice as large as the eastern ones. 


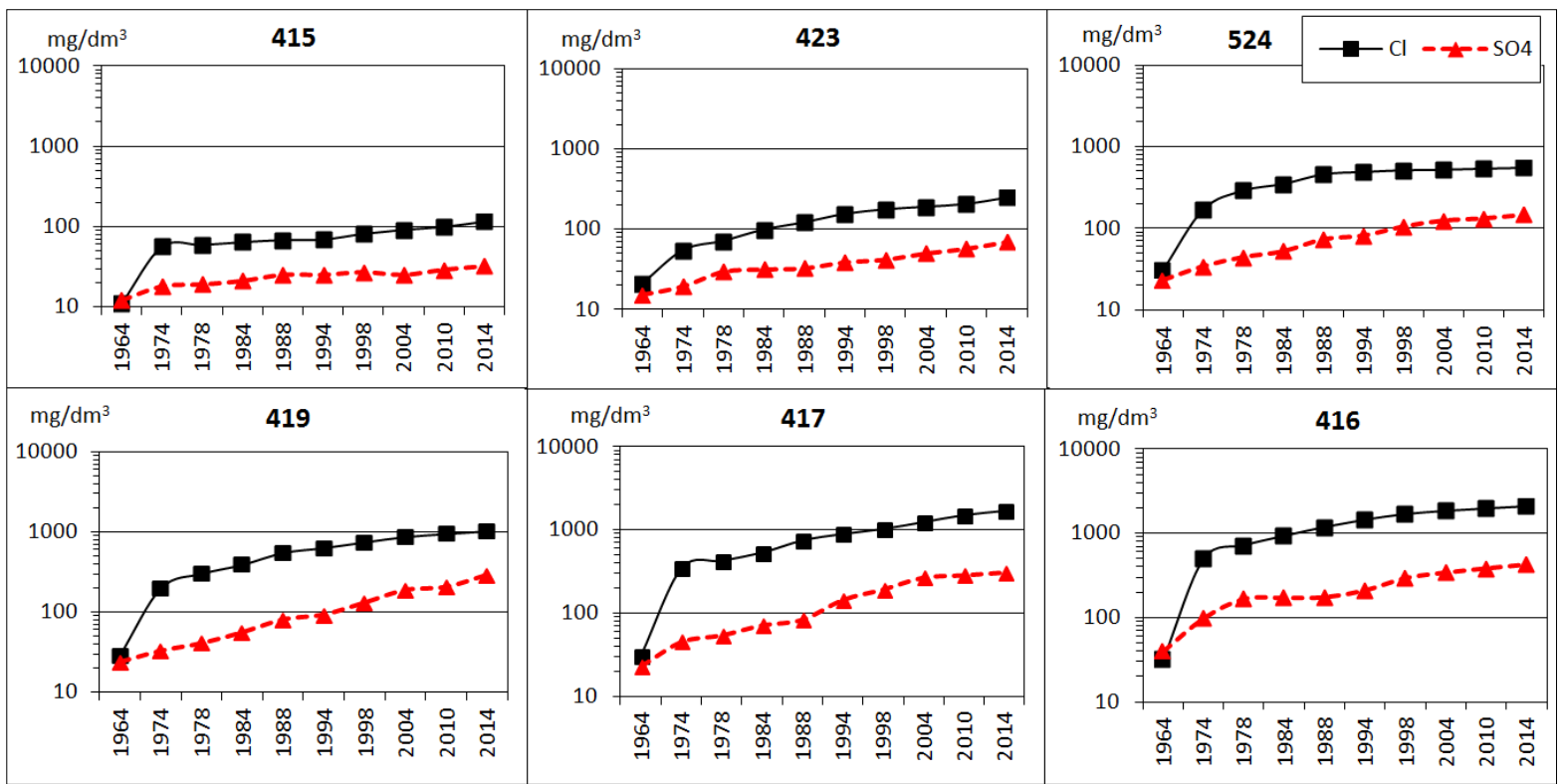

Figure 2. Evolution of the chloride and sulphate concentrations measured in the pumping wells.

Cross sections in the direction perpendicular to the sea coast (Fig. 3) show that the spatial extent of saltwater intrusion is limited to a relatively narrow zone along the coast. The concentrations of $\mathrm{Cl}$ in observation wells $204,237,575$ in 2014 were at the same level as measured in the intake wells in 1964, before the abstraction started.

Vertical variability of $\mathrm{Cl}$ distribution is clearly seen in the eastern wells 416,417 , see Fig. 4. Concentration increases approximately linearly with depth and the relative differences in chloride concentration between the top of the aquifer and well bottom are about $20 \%$. This is consistent with the well-known pattern of seawater intrusion, where the more saline water occupies the lower part of the aquifer. In contrast, the results for western wells, where the salinity is lower, do not show any appreciable differences of vertical chloride distribution.

Hydrogeochemical groundwater types were determined following Stuyfzand (1989) and listed in Table 1. They are listed in Table 1. With respect to the major ion composition, in 5 of 6 pumping wells water was of $\mathrm{NaCl}$ type, which indicates considerable sea influence. The only exception was the westernmost well 415 where water was of $\mathrm{CaHCO} 3$ type, characteristic for shallow terrestrial groundwater. The salinity, represented by the main type of water changed gradually from brackish-saline in well 416 (similar to the Baltic Sea) to fresh in well 415. The three monitoring wells located away from the sea had fresh CaHCO3 water. All groundwater samples represented 8 alkalinity type (extreme alkalinity). Furthermore, we calculated the Base Exchange Index, as an indicator of cation exchange related to salinization or freshening of the aquifer (Walraevens \& van Camp 2004). The calculation was based on the procedure outlined by Stuyfzand (2008). In almost all cases BEX was 0 , indicating equilibrium conditions with respect to cation composition. The only exception occurred in well 204, where BEX was positive. Thus it seems that the composition of water is a result of simple mixing due to dispersion and diffusion, without much ion exchange. 


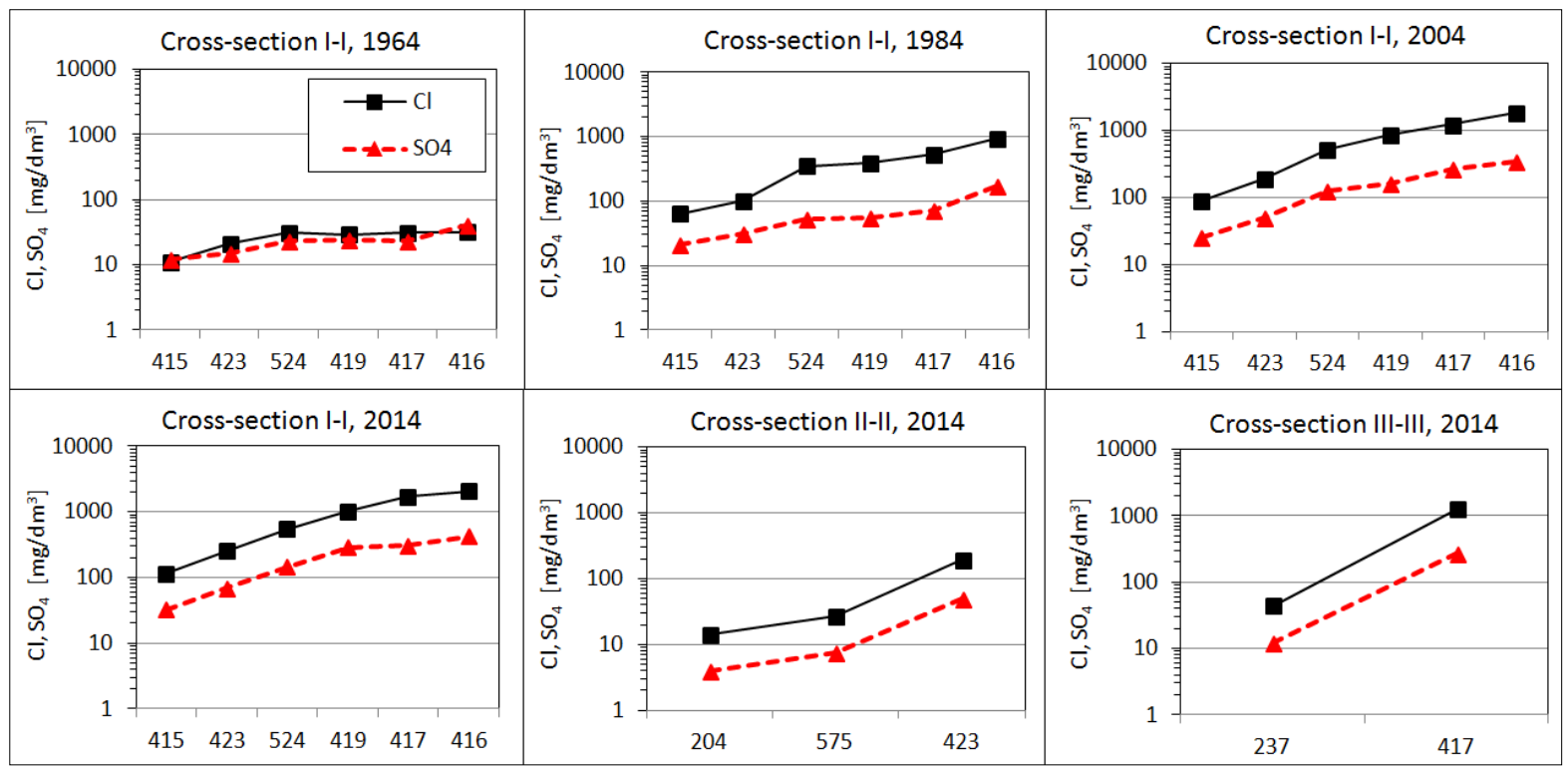

Figure 3. Concentration distribution along cross-sections.

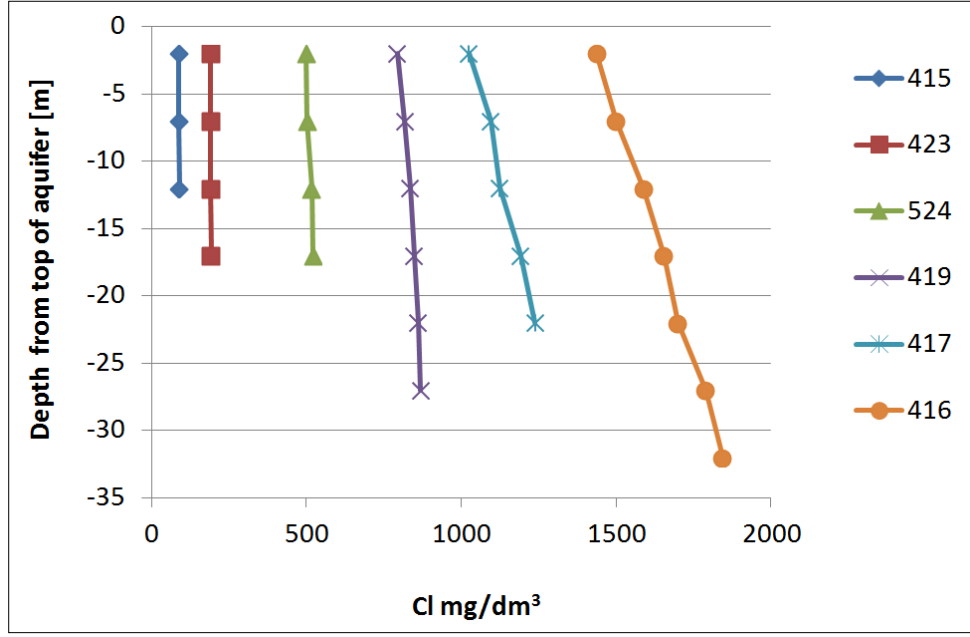

Figure 4. Vertical profiles of chloride concentration measured in pumping wells in 2004.

Table 1. Hydrogeochemical parameters of water samples (2014).

\begin{tabular}{|c|c|c|c|c|c|c|}
\hline Well number & Type & $\mathbf{N a} / \mathbf{C l}$ & $\mathbf{( C a}+\mathbf{M g}) / \mathbf{C l}$ & $\left.\mathbf{C a} / \mathbf{( S O}_{4}+\mathbf{H C O}_{3}\right)$ & $\mathbf{C a} / \mathbf{M g}$ & $\mathbf{C l} / \mathbf{B r}$ \\
\hline Baltic Sea & $\mathrm{b} 7-\mathrm{NaCl}(0)$ & 0.86 & 0.27 & 0.37 & 0.33 & 297 \\
\hline 416 & $\mathrm{~b} 8-\mathrm{NaCl}(0)$ & 0.86 & 0.30 & 0.44 & 0.49 & 310 \\
\hline 417 & $\mathrm{~b} 8-\mathrm{NaCl}(0)$ & 0.86 & 0.36 & 0.47 & 0.57 & 318 \\
\hline 419 & $\mathrm{~b} 8-\mathrm{NaCl}(0)$ & 0.86 & 0.47 & 0.53 & 0.82 & 320 \\
\hline 524 & $\mathrm{~B} 8-\mathrm{NaCl}(0)$ & 0.87 & 0.47 & 0.60 & 1.31 & 326 \\
\hline 423 & $\mathrm{f} 8-\mathrm{NaCl}(0)$ & 0.88 & 0.75 & 0.66 & 2.29 & 332 \\
\hline 415 & $\mathrm{~F} 8-\mathrm{CaHCO} 3(0)$ & 0.90 & 1.35 & 0.69 & 3.58 & 337 \\
\hline 237 & $\mathrm{~F} 8-\mathrm{CaHCO} 3(0)$ & 1.05 & 4.68 & 0.71 & 5.18 & 338 \\
\hline 575 & $\mathrm{~F} 8-\mathrm{CaHCO} 3(0)$ & 1.06 & 7.00 & 0.72 & 5.80 & 338 \\
\hline 204 & $\mathrm{~g} 8-\mathrm{CaHCO} 3(+)$ & 1.26 & 11.88 & 0.72 & 6.56 & 350 \\
\hline
\end{tabular}

Other indices reported in Table 1 also show a clear gradation of chemical composition along the line of wells. The indices of water in wells 416 and are quite similar to seawater, while the characteristics of water in well 415 are closer to the fresh groundwater from inland wells. 
The ratios $\mathrm{Na} / \mathrm{Cl},(\mathrm{Mg}+\mathrm{Ca}) / \mathrm{Cl}, \mathrm{Ca} /\left(\mathrm{SO}_{4}+\mathrm{HCO}_{3}\right), \mathrm{Ca} / \mathrm{Mg}$ and $\mathrm{Cl} / \mathrm{Br}$ increase gradually along the line of wells from east to west. The inland monitoring wells have distinctly different water with $\mathrm{Na} / \mathrm{Cl}>1$ and $(\mathrm{Ca}+\mathrm{Mg}) / \mathrm{Cl}>>1$ and $\mathrm{Ca} / \mathrm{Mg}>5$. The data in Table 1 is consistent with salinity profiles in Fig. 3, showing a gradual, significant changes of composition between along the line of pumping wells and clear differences between the pumping wells and the inland monitoring wells.

\section{CONCLUSIONS}

Significant temporal and spatial variability of groundwater chemical composition was observed in the considered aquifer in Władysławowo. The salinity of groundwater, which is associated with the marine water intrusion, has a limited spatial extent, and does not penetrate to a large distance into the aquifer in the landward direction. The zone of saltwater intrusion is located near the groundwater intake, in a flat coastal area, about $600-1000 \mathrm{~m}$ from the sea. Remarkable variability of chemical composition was observed along the line of pumping wells, parallel to the coast. The largest encroachments of seawater occurred in the eastern well despite their low pumping rates. On the other hand, the westernmost well showed only a slight influence of seawater. These differences can be explained by local variability of geological structure and natural hydraulic gradient in the aquifer.

\section{REFERENCES}

Appelo, C. A. J., \& Postma, D. (2004). Geochemistry, groundwater and pollution. CRC press.

Bear, J., Cheng, A. H. D., Sorek, S., Ouazar, D., \& Herrera, I. (Eds.). (1999). Seawater intrusion in coastal aquifers: concepts, methods and practices (Vol. 14). Springer Science \& Business Media.

Kozerski, B., Pruszkowska, M., 1996. The Origin of groundwater salinity on the Polish Baltic Sea coast. (in Polish). Inżynieria Morska i Geotechnika, 1, 46-48.

Macioszczyk, A., 1987. Hydrogeochemia (in Polish). Wyd. Geol., Warszawa.

Pruszkowska, M., 2005. Hydrogeological conditions and quality of groundwater on the tertiary sediments on Kępa Swarzewska (in Polish with English summary). Inżynieria Morska i Geotechnika, 5, 373-376.

Pruszkowska, M., Malina, G., 2008. Hydrogeochemistry and vulnerability of groundwater in the moraine upland aquifers of the Gdańsk region (Northern Poland). Geological Quarterly, 52 (3), 291 300 .

Stuyfzand, P.J. (1989) A new hydrochemical classification of water types. in: Regional Characterization of Water Quality, IAHS Publ. 182.

Stuyfzand, P.J. (2008) Base exchange indices as indicators of salinization or freshening of (Coastal) Aquifers. Proceedings of the 20th Salt Water Intrusion Meeting, Naples, FL, USA.

Walraevens K., van Camp M. (2004) Advances in understanding natural groundwater quality controls in coastal aquifers. Proceedings of 18th Salt Water Intrusion Meeting, Cartagena, Spain.

Contact Information: M. Pruszkowska-Caceres, Gdańsk University of Technology, Faculty of Civil and Environmental Engineering, 80-233 Gdańsk, Narutowicza 11/12, Email: mpru@pg.edu.pl 